\title{
Timing of Inhibitory Actions of Gossypol on Cultured Bovine Embryos
}

\author{
J. Hernández-Cerón, ${ }^{1}$ F. D. Jousan, ${ }^{2}$ P. Soto, ${ }^{2, \star}$ and P. J. Hansen ${ }^{2}$ \\ ${ }^{1}$ Departamento de Reproducción, Facultad de Medicina Veterinaria y Zootecnia \\ Universidad Nacional Autónoma de México, México D.F. 14000, México \\ ${ }^{2}$ Department of Animal Sciences, University of Florida, Gainesville 32611-0910
}

\begin{abstract}
Culture of bovine preimplantation embryos with gossypol, a polyphenolic pigment in cottonseed, inhibits development. Neither stage at which embryos are most sensitive to gossypol, nor the mechanism by which development is blocked is known. Our objectives were to characterize stages at which gossypol inhibits embryonic development and evaluate involvement of apoptosis in actions of gossypol. When presumptive 1cell embryos were cultured continuously in medium containing gossypol at concentrations of $0,2.5,5$, and $10 \mu \mathrm{g} / \mathrm{mL}$, cleavage rate was not reduced by any concentration of gossypol, but percentages of 1-cell embryos that became blastocysts $8 \mathrm{~d}$ after insemination was reduced by the $10 \mu \mathrm{g} / \mathrm{mL}$ dose of gossypol. Culture of presumptive 1-cell embryos with gossypol at $10 \mu \mathrm{g} / \mathrm{mL}$ for $24 \mathrm{~h}$ was not sufficient to block development. Furthermore, gossypol did not affect development to the blastocyst stage when 2-cell embryos were cultured with gossypol at $10 \mu \mathrm{g} / \mathrm{mL}$ for $24 \mathrm{~h}$ or $7 \mathrm{~d}$. Culture of embryos $\geq 16$ cells with gossypol at $10 \mu \mathrm{g} / \mathrm{mL}$ for 24 $\mathrm{h}$ failed to reduce cell number $24 \mathrm{~h}$ later or increase blastomere apoptosis. Results indicate that embryonic development can be disrupted by long-term exposure to gossypol at $10 \mu \mathrm{g} / \mathrm{mL}$ and that exposure at the 1-cell stage is required. Thus, it is likely that the deleterious effects of gossypol involve disruption of events at the 1-cell stage and such effects are reversible if gossypol is removed. After the 1-cell stage, gossypol does not affect development because the critical event that gossypol disrupts occurs at the 1-cell stage only or the embryo develops cytoprotective mechanisms after the 1-cell stage that limit actions of gossypol.
\end{abstract}

(Key words: gossypol, embryo, apoptosis)

Abbreviation key: BE2 = bovine embryo 2, IVF = in vitro fertilization, KSOM = potassium simplex opti-

Received August 30, 2004.

Accepted November 30, 2004.

Corresponding author: P. J. Hansen; e-mail: hansen@animal. ufl.edu.

*Present address: Faculté de Médecine Vétérinaire - CRRA, Université de Montréal, St-Hyacinthe, QC, Canada, J2S 7C6. mized medium, $\mathbf{P V P}=$ polyvinylpyrollidone, $\mathbf{T A L P}=$ Tyrode's acid lactate pyruvate solution, TUNEL = terminal deoxynucleotidyl transferase nick end labeling.

\section{INTRODUCTION}

Gossypol is a polyphenolic pigment found in cottonseed that has been implicated in disrupting spermatogenesis in bulls (Velasquez-Pereira et al., 1998; Cerelli and Johnson, 1999; Chenoweth et al., 2000) and in reducing the proportion of cows pregnant after insemination (Santos et al., 2003). Reduction in female fertility is likely due, at least in part, to disruption of embryonic function because culture of bovine embryos with gossypol inhibited development (Zirkle et al., 1988; Brocas et al., 1997). Concentrations shown to inhibit development (5 to $12.5 \mu \mathrm{g} / \mathrm{mL}$ ) are less than the $16 \mu \mathrm{g} / \mathrm{mL}$ concentration found in the endometrium of heifers fed a diet high in gossypol (Velasquez-Pereira et al., 2002) and are similar to plasma concentrations associated with decreased fertility in lactating cows (Santos et al., 2003).

The mechanism by which gossypol inhibits embryonic development is not known, but in other cells, gossypol exerts several effects that could be deleterious to development if induced in embryos. Among these actions are generation of free radicals (Fornes et al., 1993; Kovacic, 2003), alteration of ion transport (Cheng et al., 2003), disruption of cell-to-cell communication (Hervé et al., 1996), and induction of apoptosis (Ergun et al., 2004).

One characteristic of preimplantation embryos is that their resistance to certain types of stress increases as development proceeds. In cattle, for example, embryos at more advanced cleavage stages have increased resistance to heat shock (Edwards and Hansen, 1997; Krininger et al., 2002; Paula-Lopes et al., 2003; Sakatani et al., 2004). Such developmental acquisition of resistance, however, does not occur for other stresses. Examples in cattle include embryonic resistance to exposure to hydrogen peroxide (Morales et al., 1999) and arsenic (Krininger et al., 2002).

The objectives of the present series of experiments were to characterize stages of development at which gossypol inhibits embryonic development and evaluate involvement of apoptosis in actions of gossypol. 


\section{MATERIALS AND METHODS}

\section{Materials}

Sperm Tyrode's Lactate solution and HEPES Tyrode's Lactate solution were purchased (Cell and Molecular Technologies, Inc., Lavallete, NJ) and used to prepare Sperm-Tyrode's albumin lactate pyruvate (TALP), in vitro fertilization (IVF)-TALP, and HEPESTALP as described previously (Parrish et al., 1986). Bovine steer serum was purchased from Pel-Freez (Rogers, AR) and Percoll from Amersham Pharmacia Biotech (Uppsala, Sweden). Follicle stimulating hormone was Folltropin-V from Vetrepharm Canada (London, $\mathrm{ON}$ ) and was purchased from Agtech (Manhattan, KS). Medium-199 with Hank's salts and without phenol red was obtained from Atlanta Biologicals (Norcross, GA) and was used to prepare oocyte collection medium by adding $2 \%$ (vol/ $/ \mathrm{vol}$ ) bovine steer serum, $0.04 \mathrm{U}$ of hepa$\mathrm{rin} / \mathrm{mL}, 100 \mathrm{U}$ of penicillin-G/mL, $0.1 \mathrm{mg}$ of streptomy$\mathrm{cin} / \mathrm{mL}$, and $1 \mathrm{~m} M$ glutamine. Medium-199 with Earle's salts (Cell and Molecular Technologies) was used to prepare oocyte maturation medium by the addition of $10 \%$ (vol $/ \mathrm{vol}$ ) steer serum, $2 \mu \mathrm{g} / \mathrm{mL}$ of estradiol $-17 \beta, 20$ $\mu \mathrm{g} / \mathrm{mL}$ of FSH, $22 \mu \mathrm{g} / \mathrm{mL}$ of sodium pyruvate, $50 \mu \mathrm{g} /$ $\mathrm{mL}$ of gentamicin, and an additional $1 \mathrm{~m} M$ glutamine. Potassium simplex optimized medium (KSOM; Cell and Molecular Technologies) was used to prepare KSOM-bovine embryo 2 (BE2) as described elsewhere (Soto et al., 2003a).

Gossypol (+/- isomers) was purchased from Sigma (St. Louis, MO) and dissolved to a concentration of 20 $\mathrm{mg} / \mathrm{mL}$ in ethanol before dilution in culture medium so that the final concentration of ethanol was $1 \%$ (wt/wt). All other chemicals were obtained from Sigma or Fisher Scientific (Pittsburgh, PA).

\section{In Vitro Production of Embryos}

Cumulus-oocyte complexes were collected from ovaries obtained from a local slaughterhouse by slicing the surface of each ovary using previously described procedures (Soto et al., 2003a). Cumulus-oocyte complexes having at least 1 layer of compact cumulus cells were washed 3 times and matured in groups of 10 in $50-\mu \mathrm{L}$ drops of oocyte maturation medium overlaid with mineral oil for $22 \mathrm{~h}$ at $38.5^{\circ} \mathrm{C}$ in an atmosphere of $5 \%$ (vol/vol) $\mathrm{CO}_{2}$ in humidified air. For fertilization, groups of 30 cumulus-oocyte complexes were transferred to 4well plates containing $600 \mu \mathrm{L}$ of IVF-TALP per well. Frozen-thawed sperm were purified by centrifugation on a Percoll gradient and resuspended in IVF-TALP to give an approximate concentration of 4 to 6 million spermatozoa $/ \mathrm{mL}$. Oocytes were fertilized by adding a $25-\mu \mathrm{L}$ sperm suspension and $25 \mu \mathrm{L}$ of a solution of 0.5 $\mathrm{m} M$ penicillamine, $0.25 \mathrm{~m} M$ hypotaurine, and $25 \mu M$ epinephrine in $0.9 \%$ (wt/vol) $\mathrm{NaCl}$ to each well. For each replicate, sperm were prepared from a pool of semen from 3 bulls and a different pool of bulls was used for each replicate. Presumptive zygotes were removed from the fertilization wells and denuded of cumulus cells by vortex mixing in $1 \mathrm{~mL}$ of HEPES-TALP containing hyaluronidase (1000 units/mL). After washing 3 times (twice in HEPES-TALP and then once in KSOM-BE2), groups of embryos were cultured in pre-equilibrated 25or $50-\mu \mathrm{L}$ drops of modified KSOM-BE2, overlaid with mineral oil at $38.5^{\circ} \mathrm{C}$ in $5 \% \mathrm{CO}_{2}$. Embryos were assigned at random to drops. The number of embryos per drop was similar for each treatment within a replicate. Culture continued until d 8 after insemination.

\section{Gossypol Added at the One-Cell Stage}

At $8 \mathrm{~h}$ after insemination, presumptive zygotes were transferred in groups (25 to 30 each) to $50-\mu \mathrm{L}$ microdrops of KSOM-BE2 medium containing gossypol at 0 , $2.5,5$, or $10 \mu \mathrm{g} / \mathrm{mL}$ in $1 \%$ ( $\mathrm{vol} / \mathrm{vol}$ ) ethanol. Cleavage rate was determined at $\mathrm{d} 3$ after insemination and development to blastocyst stage was determined at $\mathrm{d} 8$. The experiment was replicated 6 times with a total of 179 to 242 presumptive zygotes (i.e., oocytes subjected to insemination) per treatment.

A second experiment was performed to determine the effect of duration of exposure to gossypol beginning at the 1-cell stage on embryonic development. The design was a $2 \times 2$ factorial with main effects of gossypol (+ or - ) and duration of exposure ( $24 \mathrm{~h}$ or $8 \mathrm{~d}$ ). At $8 \mathrm{~h}$ after insemination, presumptive zygotes were transferred in groups (25 to 30 each) to $50-\mu \mathrm{L}$ drops of KSOM-BE2 medium or KSOM-BE2 medium containing $1 \%$ (vol/vol) ethanol and gossypol (0 or $10 \mu \mathrm{g} / \mathrm{mL}$ ). Embryos were cultured with gossypol for either $24 \mathrm{~h}$ or $8 \mathrm{~d}$. For the 24-h groups, embryos were washed twice in drops of KSOM-BE2 after incubation for $24 \mathrm{~h}$, transferred to a fresh drop of KSOM-BE2 without gossypol or ethanol, and cultured until d 8. For 8-d exposure, embryos were cultured in the same medium from $8 \mathrm{~h}$ after fertilization until $\mathrm{d}$ 8. In addition to the 4 treatments described above, a control group of embryos cultured without ethanol from $8 \mathrm{~h}$ after insemination until d 8 after insemination was included for each replicate. Cleavage rate was determined at $\mathrm{d} 3$ after insemination and development to the blastocyst stage was determined at $\mathrm{d} 8$. The experiment was replicated 6 times with a total of 237 to 268 presumptive zygotes per treatment.

\section{Gossypol Added at the Two-Cell Stage}

Two-cell embryos were collected 30 to $31 \mathrm{~h}$ after insemination and transferred to fresh $25-\mu \mathrm{L}$ drops of 
Table 1. Effect of gossypol added $8 \mathrm{~h}$ after insemination on cleavage rate and blastocyst development. ${ }^{1}$

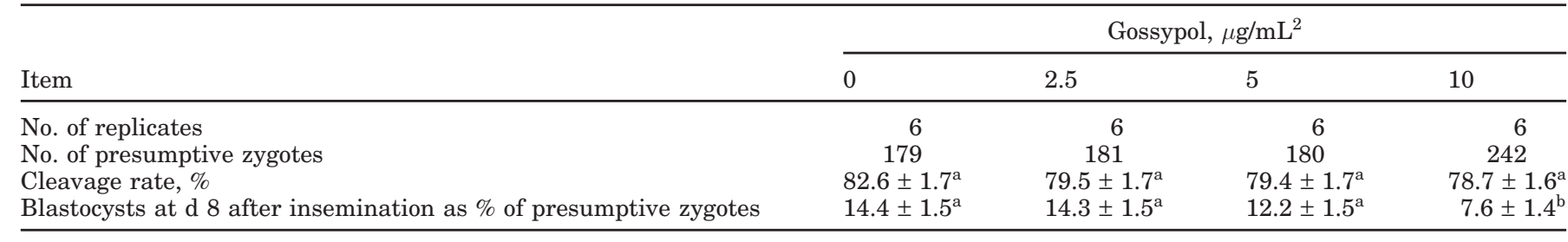

${ }^{a, b}$ Values in the same row having different superscript letters differ $(P<0.05)$.

${ }^{1}$ Data are least squares means $\pm \mathrm{SEM}$ of percentage values calculated for each replicate.

${ }^{2}$ All treatments contained $1 \%$ (vol/vol) ethanol.

KSOM-BE2 medium (8 to 18 embryos per drop) containing $1 \%(\mathrm{vol} / \mathrm{vol})$ ethanol and gossypol $(0,2.5,5$, or $10 \mu \mathrm{g} / \mathrm{mL}$ ). Development to the blastocyst stage was determined on $\mathrm{d} 8$ after insemination. The experiment was replicated 7 to 13 times with a total of 111 to 338 embryos per treatment. Replication was unequal because for 6 or 13 replicates, embryos were assigned to gossypol ( 0 and $10 \mu \mathrm{g} / \mathrm{mL}$ ) treatments only because of the limited number of embryos.

Another experiment was performed to test effects on 2-cell embryos of 24-h exposure to gossypol. Two-cell embryos collected 30 to $31 \mathrm{~h}$ after insemination were transferred to fresh $25-\mu \mathrm{L}$ drops of KSOM-BE2 medium (10 to 20 embryos per drop) containing $1 \%$ (vol/vol) ethanol and gossypol ( 0 or $10 \mu \mathrm{g} / \mathrm{mL})$ and cultured for 24 h. Embryos were then washed twice in drops of KSOMBE2, transferred to a fresh drop of KSOM-BE2 without gossypol or ethanol, and cultured until d 8 after insemination when development to the blastocyst stage was determined. The experiment was replicated 6 times with a total of 118 to 129 embryos per treatment.

\section{Effects of Gossypol on Cell Number and Apoptosis}

Embryos $\geq 16$ cells were collected on d 5 after insemination and transferred to $25 \mu \mathrm{L}$ of KSOM-BE2 (medium control), KSOM-BE2 containing 1\% (vol/vol) ethanol (vehicle control) or KSOM-BE2 containing gossypol (10 $\mu \mathrm{g} / \mathrm{mL})$ and $1 \%(\mathrm{vol} / \mathrm{vol})$ ethanol. After culture at $38.5^{\circ} \mathrm{C}$ for $24 \mathrm{~h}$, embryos were processed for determination of total cell numbers and apoptotic cells using the terminal deoxynucleotidyl transferase nick end labeling (TUNEL) assay as outlined below. The experiment was replicated 6 times using 81 to 104 embryos per treatment. Embryos were used at 5 after insemination for this assay to ensure they were sufficiently advanced in development to be capable of induced apoptosis responses (Paula-Lopes and Hansen, 2002).

For the TUNEL assay, embryos were fixed in $4 \%$ (wt/ vol) paraformaldehyde for $1 \mathrm{~h}$, washed in $10 \mathrm{mM} \mathrm{KPO}_{4}$ $(\mathrm{pH}$ 7.4) containing $0.9 \%$ (wt/vol) $\mathrm{NaCl}$ (PBS) containing polyvinylpyrollidone (PVP) at $1 \mathrm{mg} / \mathrm{mL}$ and permeabilized in $50 \mu \mathrm{L}$ of $0.5 \%$ (vol/vol) Triton X-100 containing $0.1 \%(\mathrm{wt} / \mathrm{vol})$ sodium citrate for $30 \mathrm{~min}$ at room temperature. Positive controls were incubated in $25 \mu \mathrm{L}$ of RQ1 RNase-free DNase $(50 \mathrm{U} / \mathrm{mL})$ at $37^{\circ} \mathrm{C}$ for $1 \mathrm{~h}$. Embryos were washed in PBS-PVP and incubated in $25 \mu \mathrm{L}$ of TUNEL reaction mixture containing fluorescein isothiocyanate-conjugated dUTP, and the enzyme terminal deoxynucleotidyltransferase, as prepared by the manufacturer (Roche, Indianapolis, IN),

Table 2. Effect of duration of gossypol exposure added $8 \mathrm{~h}$ after insemination on cleavage rate and blastocyst development at $\mathrm{d} 8$ after insemination. ${ }^{1}$

\begin{tabular}{|c|c|c|c|c|}
\hline \multirow[b]{3}{*}{ Item } & \multicolumn{4}{|c|}{ Duration of exposure } \\
\hline & \multicolumn{4}{|c|}{ Gossypol, $\mu \mathrm{g} / \mathrm{mL}^{2}$} \\
\hline & 0 & 10 & 0 & 10 \\
\hline No. of replicates & 6 & 6 & 6 & 6 \\
\hline No. of presumptive zygotes & 237 & 268 & 241 & 240 \\
\hline
\end{tabular}


for $1 \mathrm{~h}$ in the dark at $37^{\circ} \mathrm{C}$. Negative controls were incubated in the absence of terminal deoxynucleotidyltransferase for $1 \mathrm{~h}$ in the dark at $37^{\circ} \mathrm{C}$. Embryos were washed in PBS-PVP and incubated in $25 \mu \mathrm{L}$ of Hoechst $33342(1 \mu \mathrm{g} / \mathrm{mL})$ for $10 \mathrm{~min}$ in the dark at room temperature. Embryos were washed twice to remove excess Hoechst 33342 and mounted on poly-L-lysine coated (1:10 in PBS) microscope slides using $4 \mu \mathrm{L}$ of glycerol. Each embryo was analyzed for total cell number and TUNEL-positive nuclei with ultraviolet and FITC (fluorescein isothiocyanate) filters, respectively, using a Zeiss Axioplan 2 fluorescence microscope (Carl Zeiss, Inc., Göttingen, Germany).

\section{Statistical Analyses}

For each replicate, percentages of presumptive zygotes that cleaved and percentages of embryos that developed to the blastocyst stage were calculated for all embryos within the same treatment. Thus, the group of embryos treated alike within each replicate was the experimental unit. For data on cell number and percentage TUNEL-positive cells, embryo was the experimental unit. Data were subjected to least squares ANOVA using the GLM procedure of the Statistical Analysis System (SAS for Windows, Release 8.02, SAS Institute, Inc., Cary, NC). Percentage data were analyzed without transformation and again after arcsin transformation to correct for any non-normality associated with percentage data. All main effects and interactions were included in the mathematical models for ANOVA. Replicate was considered random and other main effects were considered fixed. Thus, treatment $\times$ replicate was the error term for treatment. Data are reported as least squares means \pm SEM. When transformation was applied, least squares means \pm SEM are from the untransformed data and probability values are derived from analyses of transformed data. In one experiment, the number of replicates differed among treatments, and least squares means (but not $F$-tests) were obtained after removing the treatment $\times$ replicate interaction from the model. Differences between various levels of a main effect were determined using the pdiff mean separation test of SAS or by partitioning treatment effects into individual comparisons (medium control vs. others; vehicle control vs. gossypol) using orthogonal contrasts. Data for cell number and apoptosis were analyzed similarly except that the experimental unit was embryo.

\section{RESULTS}

\section{Timing of Effects of Gossypol}

Addition of gossypol $8 \mathrm{~h}$ after insemination had no effect on subsequent cleavage rate of presumptive zy- gotes, but the proportion that developed to the blastocyst stage at d 8 after insemination was reduced $(P<$ 0.05 ) by gossypol at $10 \mu \mathrm{g} / \mathrm{mL}$ (Table 1 ).

A second experiment was conducted to determine whether short-term treatment with gossypol would reduce embryonic development (Table 2). Although exposure to gossypol $(10 \mu \mathrm{g} / \mathrm{mL})$ from $8 \mathrm{~h}$ after insemination until d 8 after insemination reduced the proportion of presumptive zygotes that developed to the blastocyst stage, no effect was detected for gossypol added for 24 h only (gossypol $\times$ duration; $P<0.05$ ). In this experiment, a control consisting of embryos cultured without ethanol or gossypol from $8 \mathrm{~h}$ after insemination until d 8 after insemination was included. A greater proportion of these embryos developed to the blastocyst stage at $\mathrm{d} 8$ after insemination than for embryos cultured with the ethanol vehicle $(21.7 \pm 1.6$ vs. $13.0 \pm 1.5 \%$; $P$ $<0.05$ ).

Addition of gossypol to embryos harvested as 2-cell embryos at 30 to $31 \mathrm{~h}$ after insemination had no effect on the proportion of embryos that became blastocysts. This was the case whether gossypol was present continuously until d 8 after insemination (Table 3) or was present for $24 \mathrm{~h}$ only beginning at 30 to $31 \mathrm{~h}$ after insemination (Table 4).

\section{Possible Antiproliferative and Proapoptotic Actions of Gossypol on Embryos at Day 5}

The effect of 24-h culture with gossypol on total cell number and apoptosis was examined in embryos $\geq 16$ cells collected at d 5 after insemination (Table 5). No significant difference was detected among embryos treated with gossypol at $10 \mu \mathrm{g} / \mathrm{mL}$ and those treated with the $1 \%$ (vol/vol) ethanol vehicle for total cell number or percentage of TUNEL-positive nuclei. Both treatments together, however, had fewer $(P<0.05)$ total cell numbers and more $(P<0.01)$ TUNEL-positive nuclei compared with control embryos cultured without ethanol.

\section{DISCUSSION}

It is well known that gossypol can inhibit embryonic development (Zirkle et al., 1988; Brocas et al., 1997) and this antiembryonic action of gossypol is likely one reason that feeding lactating cows diets containing gossypol reduced fertility (Santos et al., 2003). Present results indicate that the period of embryonic development most sensitive to disruption by gossypol is narrow and limited largely to the first $24 \mathrm{~h}$ after insemination. This conclusion is based on the observation that adding gossypol immediately after fertilization $(\sim 8 \mathrm{~h}$ postinsemination) reduced the proportion of oocytes that be- 
Table 3. Effect of gossypol added from the 2-cell stage until d 8 after insemination on blastocyst development at $\mathrm{d} 8 .^{1}$

\begin{tabular}{lcccc}
\hline & \multicolumn{4}{c}{ Gossypol, $\mu \mathrm{g} / \mathrm{mL}^{2}$} \\
\cline { 2 - 5 } Item & 0 & 2.5 & 5 & 10 \\
\hline No. of replicates & 13 & 7 & 7 & 13 \\
No. of embryos & 210 & 115 & 111 & 338 \\
Blastocysts, \% of 2-cell embryos & $27.3 \pm 3.4$ & $26.6 \pm 5.3$ & $24.3 \pm 5.3$ & $23.3 \pm 3.4$ \\
\hline
\end{tabular}

${ }^{1}$ Data are least squares means \pm SEM of percentage values calculated for each replicate (obtained from model without concentration $\times$ replicate).

${ }^{2}$ All treatments contained $1 \%$ (vol/vol) ethanol.

came blastocysts. No deleterious effects of gossypol were detected when gossypol was added at the 2-cell stage ( $\sim 30$ to $31 \mathrm{~h}$ after insemination) or to embryos $\geq 6$ cells at $\mathrm{d} 5$ after insemination. It cannot be determined whether the critical event that gossypol disrupts occurs at the 1-cell stage only or whether the embryo develops cytoprotective mechanisms after the 1-cell stage that limit actions of gossypol. Synthesis of heat-shock protein 70 in response to heat shock, for example, occurs at the 2-cell stage but not in mature oocytes (Edwards and Hansen, 1996).

The above discussion leads to the question of the mechanism by which gossypol inhibits development. Gossypol can lead to an increase in intracellular calcium ion concentrations via release from the endoplasmic reticulum, and influx from outside the cell (Cheng et al., 2003). Such an effect might affect signaling events in the 1-cell embryo (Nakada and Mizuno, 1998; Tosti et al., 2002). Another action of gossypol is to increase free radical production (Fornes et al., 1993; Kovacic, 2003) and addition of hydrogen peroxide to bovine embryos blocked development (Morales et al., 1999). Embryos do not seem to acquire increased resistance to hydrogen peroxide as development advances, however (Morales et al., 1999). Gossypol can induce apoptosis (Ergun et al., 2004), but no increase in TUNEL-positive cells was detected in embryos $\geq 16$ cells when exposed to gossypol. This stage was chosen for analysis of apoptosis responses because several other stimuli, including heat shock (Paula-Lopes and Hansen, 2002), arsenic (Krininger et al., 2002), and tumor necrosis fac- tor- $\alpha$ (Soto et al., 2003b) induce apoptosis in embryos $\geq 16$ cells.

One possibility for the increased susceptibility of the 1-cell embryo to gossypol exposure is transcriptional inactivity at this stage of development. Although the major round of activation of the embryonic genome occurs at the 8-to-16-cell stage (Memili and First, 2000), some transcription occurs as early as the 2-cell stage (Viuff et al., 1996), and heat shock can regulate HSP70 gene expression at this stage (Chandolia et al., 1999). Problems inherent in selecting embryos for experiments might lead to apparent stage-specific differences in response to a stress that are, in fact, due to embryonic selection. In the current studies, for example, the 2-cell embryos were harvested 30 to $31 \mathrm{~h}$ after insemination. Thus, embryos that cleaved early were more likely to be used for experimentation than embryos that cleaved later (after 30 to $31 \mathrm{~h}$ ). Earlier-cleaving embryos have superior developmental competence (Ward et al., 2001) and the molecular basis for superior development of these embryos might confer increased tolerance to stress. Among the transcripts elevated in earlier-cleaving embryos is that for IGF-I (Lonergan et al., 2000).

Given that the 1-cell embryo seems especially sensitive to gossypol, one unexpected observation was the failure of gossypol exposure for $24 \mathrm{~h}$ to block development of 1-cell embryos. This phenomenon is interpreted to represent the reversibility of actions of gossypol at the 1-cell stage. Although presence of gossypol at the 1-cell stage inhibited embryonic development, removal of gossypol after $24 \mathrm{~h}$ allowed the embryos to regain

Table 4. Effect of 24-h exposure to gossypol beginning at the 2-cell stage on blastocyst development at d 8 after fertilization. ${ }^{1}$

\begin{tabular}{lcc}
\hline & \multicolumn{2}{c}{ Gossypol, $\mu \mathrm{g} / \mathrm{mL}^{2}$} \\
\cline { 2 - 3 } Item & 0 & 10 \\
\hline No. of replicates & 6 & 6 \\
No. of embryos & 118 & 129 \\
Blastocysts at d 8 after insemination, \% of 2-cell embryos & $43.0 \pm 6.7$ & $37.3 \pm 6.4$ \\
\hline
\end{tabular}

${ }^{1}$ Data are least squares means \pm SEM of percentage values calculated for each replicate.

${ }^{2}$ All treatments contained $1 \%$ (vol/vol) ethanol. 
Table 5. Effect of 24-h treatment with gossypol and ethanol beginning at d 5 after insemination on total cell number and number of TUNEL-positive nuclei. ${ }^{1,2}$

\begin{tabular}{lccc}
\hline Item & $\begin{array}{c}\text { Medium } \\
\text { control }\end{array}$ & $\begin{array}{c}\text { Ethanol } \\
\text { vehicle }\end{array}$ & Gossypol \\
\hline No. of replicates & 6 & 6 & 6 \\
No. of embryos & 89 & 104 & 81 \\
No. of cells & $59.1 \pm 2.7^{\mathrm{a}}$ & $51.9 \pm 2.6^{\mathrm{b}}$ & $51.0 \pm 2.8^{\mathrm{b}}$ \\
TUNEL-positive cells, \% of all cells & $6.0 \pm 0.6^{\mathrm{a}}$ & $9.2 \pm 0.6^{\mathrm{b}}$ & $8.2 \pm 0.7^{\mathrm{b}}$ \\
\hline a,b $V$ alues in the same row having different superscript letters differ $(P<0.05)$. & \\
${ }^{1}$ Data are least squares means \pm SEM of percentage values calculated for each replicate. & \\
${ }^{2}$ TUNEL = Terminal deoxynucleotidyl transferase nick end labeling. &
\end{tabular}

normal developmental potential. Thus, actions induced by gossypol in the 1-cell embryo that led to a reduction in developmental competence did not cause a permanent lesion in the embryo. Rather, actions of gossypol can be reversed, at least if exposure is limited to $24 \mathrm{~h}$.

In the present study, the effect of gossypol on embryo development was evaluated at several concentrations that fall within the range of values found in blood plasma of cows fed cottonseed meal (Brocas et al., 1997; Velasquez-Pereira et al., 2002; Prieto et al., 2003; Santos et al., 2003). Only the highest concentration (10 $\mu \mathrm{g} /$ $\mathrm{mL}$ ) had a negative effect on the ability of 1-cell embryos to develop at the blastocyst stage. In an earlier study, concentrations as low as $5 \mu \mathrm{g} / \mathrm{mL}$ were effective at reducing embryonic development (Brocas et al., 1997). Differences between the current study and that of Brocas et al. (1997) could reflect variation in the characteristics of the batch of gossypol, quality of oocytes obtained from the abattoir, or subtle differences in culture technique or conditions. In any case, $10 \mu \mathrm{g} / \mathrm{mL}$ represents a physiologically relevant concentration of gossypol for cattle fed cottonseed products.

One difficulty with interpretation of the present data is the fact that ethanol, which was used as a vehicle to dissolve gossypol, itself reduced development. This finding raises the possibility that effects of gossypol were exacerbated by damage caused by the ethanol carrier. Alternatively, if ethanol and gossypol exert similar actions on the embryo, it is possible that some of the deleterious actions of gossypol were masked by the ethanol carrier. Efforts to dissolve gossypol in lower and less embryotoxic concentrations of ethanol were unsuccessful. Accordingly, it is instructive to determine whether exposure to gossypol in vivo can induce similar effects as seen here. It is clear that cows fed cottonseed products that achieve tissue concentrations of $10 \mu \mathrm{g} / \mathrm{mL}$ will not necessarily experience infertility. For example, there was no adverse effect of gossypol on embryonic development in superovulated heifers fed cottonseed meal despite the heifers having concentrations of gossypol in plasma and endometrium of 5 to $7.5 \mu \mathrm{g} / \mathrm{mL}$ and $16 \mu \mathrm{g} / \mathrm{mL}$, respectively (Velasquez-Pereira et al., 2002).
The failure of gossypol to disrupt development of embryos in vivo suggests that mechanisms exist in the reproductive tract to counteract the deleterious effects of gossypol. In contrast, plasma concentrations of gossypol above 5 to $10 \mu \mathrm{g} / \mathrm{mL}$ were associated with lowered pregnancy rate per insemination for lactating dairy cows (Santos et al., 2003). One possibility is that effects of feeding cottonseed products on fertility of cattle may depend not only on the gossypol content and on availability in the feed but also on the status of cytoprotective mechanisms within the female.

In conclusion, the present results are consistent with the hypothesis that detrimental effects of gossypol on fertility in cows are mediated, in part, through direct effects of gossypol on embryonic development. The deleterious effects of gossypol in culture involved disruption of events at the 1-cell stage and such effects were reversible when gossypol was removed. After the 1-cell stage, gossypol does not affect development, either because the critical event(s) that gossypol disrupts occurs at the 1-cell stage only, or the embryo develops cytoprotective mechanisms after the 1-cell stage that limit actions of gossypol.

\section{ACKNOWLEDGMENTS}

Research was supported in part by USDA grant 200235203-12664. The authors thank William Rembert for assistance with collection of ovaries; Marshall, Alex, and Adam Chernin and employees of Central Beef Packing Co. (Center Hill, FL) for allowing access to their facilities and cooperation in obtaining ovaries; and Scott A. Randell and Southeastern Semen Services (Wellborn, FL) for providing bull semen. This is Journal Series Number R-10433 of the Florida Agricultural Experiment Station.

\section{REFERENCES}

Brocas, C., R. M. Rivera, F. F. Paula-Lopes, L. R. McDowell, M. C. Calhoun, C. R. Staples, N. S. Wilkinson, A. J. Boning, P. J. Chenoweth, and P. J. Hansen. 1997. Deleterious actions of gossypol on bovine spermatozoa, oocytes and embryos. Biol. Reprod. 57:901-907. 
Cerelli, J. S., and L. Johnson. 1999. Potential daily sperm production, Sertoli cell number, and seminiferous tubule characteristics in beef bulls fed conventional or gossypol-enriched diets. J. Androl. 20:519-528.

Chandolia, R. K., M. R. Peltier, W. Tian, and P. J. Hansen. 1999. Transcriptional control of development, protein synthesis and heat-induced heat shock protein 70 synthesis in 2 -cell bovine embryos. Biol. Reprod. 61:1644-1648.

Cheng, J. S., Y. K. Lo, J. H. Yeh, H. H. Cheng, C. P. Liu, W. C Chen, and C. R. Jan. 2003. Effect of gossypol on intracellular $\mathrm{Ca}^{2+}$ regulation in human hepatoma cells. Chin. J. Physiol. 46:117-122.

Chenoweth, P. J., C. C. Chase, Jr., C. A. Risco, and R. E. Larsen. 2000. Characterization of gossypol-induced sperm abnormalities in bulls. Theriogenology 53:1193-1203.

Edwards, J. L., and P. J. Hansen. 1996. Elevated temperature increases heat shock protein 70 synthesis in bovine two-cell embryos and compromises function of maturing oocytes. Biol. Reprod. 55:340-346.

Edwards, J. L., and P. J. Hansen. 1997. Differential responses of bovine oocytes and pre-implantation embryos to heat shock. Mol. Reprod. Dev. 46:138-145.

Ergun, M. A., E. Konac, D. Erbas, and A. Ekmekci. 2004. Apoptosis and nitric oxide release induced by thalidomide, gossypol and dexamethasone in cultured human chronic myelogenous leukemic K-562 cells. Cell Biol. Int. 28:237-242.

Fornes, M. W., A. M. Barbieri, and M. H. Burgos. 1993. Sperm motility loss induced by gossypol: relation with $\mathrm{OH}$ scavengers, motile stimulators and malondialdehyde production. Biochem. Biophys. Res. Commun. 195:1289-1293.

Hervé, J. C., F. Pluciennik, B. Bastide, L. Cronier, F. Verrecchia, A. Malassiné, M. Joffre, and J. Délezè. 1996. Contraceptive gossypol blocks cell-to-cell communication in human and rat cells. Eur. J. Pharmacol. 313:243-255.

Kovacic, P. 2003. Mechanism of drug and toxic actions of gossypol: Focus on reactive oxygen species and electron transfer. Curr. Med. Chem. 10:2711-2718.

Krininger, C. E., III, S. H. Stephens, and P. J. Hansen. 2002. Developmental changes in inhibitory effects of arsenic and heat shock on growth of pre-implantation bovine embryos. Mol. Reprod. Dev. 63:335-340.

Lonergan, P., A. Gutierrez-Adan, B. Pintado, T. Fair, F. Ward, J. D. Fuente, and M. Boland. 2000. Relationship between time of first cleavage and the expression of IGF-I growth factor, its receptor, and two housekeeping genes in bovine two-cell embryos and blastocysts produced in vitro. Mol. Reprod. Dev. 57:146-152.

Memili, E., and N. L. First. 2000. Zygotic and embryonic gene expression in cows: A review of timing and mechanisms of early gene expression as compared with other species. Zygote 8:87-96.

Morales, H., P. Tilquin, J. F. Rees, A. Massip, F. Dessy, and A. Van Langendonckt. 1999. Pyruvate prevents peroxide-induced injury of in vitro preimplantation bovine embryos. Mol. Reprod. Dev. 52:149-157.

Nakada, K., and J. Mizuno. 1998. Intracellular calcium responses in bovine oocytes induced by spermatozoa and by reagents. Theriogenology 50:269-282.
Parrish, J. J., J. L. Susko-Parrish, E. S. Crister, W. H. Eyestone, and N. L. First. 1986. Bovine in vitro fertilization with frozen-thawed semen. Theriogenology 25:591-600.

Paula-Lopes, F. F., and P. J. Hansen. 2002. Heat-shock induced apoptosis in preimplantation bovine embryos is a developmentally regulated phenomenon. Biol. Reprod. 66:1169-1177.

Paula-Lopes, F. F., Y. M. Al-Katanani, A. C. Majewski, L. R. McDowell, and P. J. Hansen. 2003. Manipulation of antioxidant status fails to improve fertility of lactating cows or survival of heatshocked embryos. J. Dairy Sci. 86:2343-2351.

Prieto, J. G., E. J. DePeters, P. H. Robinson, J. E. P. Santos, J. W. Pareas, and S. J. Taylor. 2003. Increasing dietary levels of cracked pima cottonseed increase plasma gossypol but do not influence productive performance of lactating Holstein cows. J. Dairy Sci. 86:254-267.

Sakatani, M., S. Kobayashi, and M. Takahashi. 2004. Effects of heat shock on in vitro development and intracellular oxidative state of bovine preimplantation embryos. Mol. Reprod. Dev. 67:77-82.

Santos, J. E. P., M. Villasen̈or, P. H. Robinson, E. J. DePeters, and C. A. Holmberg. 2003. Type of cottonseed and level of gossypol in diets of lactating dairy cows: Plasma gossypol, health, and reproductive performance. J. Dairy Sci. 86:892-905.

Soto, P., R. P. Natzke, and P. J. Hansen. 2003a. Identification of possible mediators of embryonic mortality caused by mastitis: Actions of lipopolysaccharide, prostaglandin $\mathrm{F}_{2 \alpha}$, and the nitric oxide generator, sodium nitroprusside dihydrate, on oocyte maturation and embryonic development in cattle. Am. J. Reprod. Immunol. 50:263-272.

Soto, P., R. P. Natzke, and P. J. Hansen. 2003b. Actions of tumor necrosis factor- $\alpha$ on oocyte maturation and embryonic development in cattle. Am. J. Reprod. Immunol. 50:380-388.

Tosti, E., R. Boni, and A. Cuomo. 2002. Fertilization and activation currents in bovine oocytes. Reproduction 124:835-846.

Velasquez-Pereira, J., C. F. Aréchiga, L. R. McDowell, P. J. Hansen, P. J. Chenoweth, M. C. Calhoun, C. A. Risco, T. R. Batra, S. N. Williams, and N. S. Wilkinson. 2002. Effects of gossypol from cottonseed meal and dietary vitamin $\mathrm{E}$ on the reproductive characteristics of superovulated beef heifers. J. Anim. Sci. 80:24852492.

Velasquez-Pereira, J., P. J. Chenoweth, L. R. McDowell, C. A. Risco, C. R. Staples, D. Prichard, F. G. Martin, M. C. Calhoun, S. N. Williams, and N. S. Wilkinson. 1998. Reproductive effects of feeding gossypol and vitamin E to bulls. J. Anim. Sci. 76:2894-2904.

Viuff, D., B. Avery, T. Greve, W. A. King, and P. Hyttel. 1996. Transcriptional activity in in vitro produced bovine two- and four-cell embryos. Mol. Reprod. Dev. 43:171-179.

Ward, F., D. Rizos, D. Corridan, K. Quinn, M. Boland, and P. Lonergan. 2001. Paternal influence on the time of first embryonic cleavage post insemination and the implications for subsequent bovine embryo development in vitro and fertility in vivo. Mol. Reprod. Dev. 60:47-55.

Zirkle, S. M., Y. C. Lin, F. C. Gwazdauskas, and R. S. Canseco. 1988. Effect of gossypol on bovine embryo development during the preimplantation period. Theriogenology 30:575-582. 